\title{
Development of refractory ceramics for the oxygen evolution reaction (OER) catalyst
} support for water steam electrolysis

Polonsky, J.; Prag, Carsten Brorson; Nikiforov, Aleksey; Petrushina, Irina; Christensen, Erik; Bjerrum, Niels

Published in:

Book of abstracts

Publication date:

2011

Link back to DTU Orbit

Citation (APA):

Polonsky, J., Prag, C. B., Nikiforov, A., Petrushina, I., Christensen, E., \& Bjerrum, N. (2011). Development of refractory ceramics for the oxygen evolution reaction (OER) catalyst support for water steam electrolysis. In Book of abstracts

\section{General rights}

Copyright and moral rights for the publications made accessible in the public portal are retained by the authors and/or other copyright owners and it is a condition of accessing publications that users recognise and abide by the legal requirements associated with these rights.

- Users may download and print one copy of any publication from the public portal for the purpose of private study or research.

- You may not further distribute the material or use it for any profit-making activity or commercial gain

- You may freely distribute the URL identifying the publication in the public portal

If you believe that this document breaches copyright please contact us providing details, and we will remove access to the work immediately and investigate your claim 
Development of refractory ceramics for the oxygen evolution reaction (OER) catalyst support for water steam electrolysis.

J. Polonský, C. B. Prag, A.V. Nikiforov*, I.M. Petrushina, E. Christensen, N.J. Bjerrum

Technical University of Denmark

Energy and Materials Science Group, Department of Chemistry, Technical University of Denmark, Kemitorvet 207, DK-2800 Kgs. Lyngby, Denmark

A new technique of stability evaluation of ceramic powders was developed. The technique involves dissolution in triflic acid/hydrogen peroxide (TA/HP) mixture at $130{ }^{\circ} \mathrm{C}$ and following analysis of dissolved components by inductively coupled plasma mass spectroscopy (ICP-MS). The acid-peroxide mixture is strongly acidic and oxidative, being able to decompose a wide range of chemical compounds. This approach was used to simulate the severe anodic conditions of high temperature PEM electrolysers and estimate the stability of catalyst support candidates.

It has been shown before, that refractory ceramic powders can be successfully employed as an electrocatalyst support in PEM systems ${ }^{1,2}$.

We have chosen four prospective supports, namely $\mathrm{TaC}$, $\mathrm{Si}_{3} \mathrm{~N}_{4}, \mathrm{Mo}_{2} \mathrm{~B}_{5}$ and $\mathrm{WB}$, which were tested for a corrosion stability in TA/HP at $130{ }^{\circ} \mathrm{C}$.

$\mathrm{TaC}$ and $\mathrm{Si}_{3} \mathrm{~N}_{4}$ proved to be reasonably stable, while $\mathrm{Mo}_{2} \mathrm{~B}_{5}$ and WB were prone to corrosion.

Therefore, the first two compounds were tested as a possible catalyst support for the $\mathrm{IrO}_{2}$ active phase and their electrochemical performance was evaluated by the thin-film electrode method ${ }^{3}$. The iridium oxide content in the electrocatalyst layer of the electrodes varied from $\mathrm{x}=0.1$ to $\mathrm{x}=0.9$, corresponding to the general formula (1-x)(Support)-x( $\left(\mathrm{IrO}_{2}\right)$. The step in compositions was 0.2 . The performance of pure $\mathrm{IrO}_{2}$ electrode was evaluated as well.

The electrochemical performance of catalysts using $\mathrm{TaC}$ and $\mathrm{Si}_{3} \mathrm{~N}_{4}$ supports was evaluated in $0.5 \mathrm{M} \mathrm{H}_{2} \mathrm{SO}_{4}$.

Neat TaC powder appeared to have conductivity very close to that of $\mathrm{IrO}_{2}$, while the conductivity of $\mathrm{Si}_{3} \mathrm{~N}_{4}$ was several orders of magnitude lower. However, the conductivity of $\mathrm{TaC}$ significantly dropped after introducing it to in-situ synthesis of $\mathrm{IrO}_{2}$ by the Adams Fusion method.

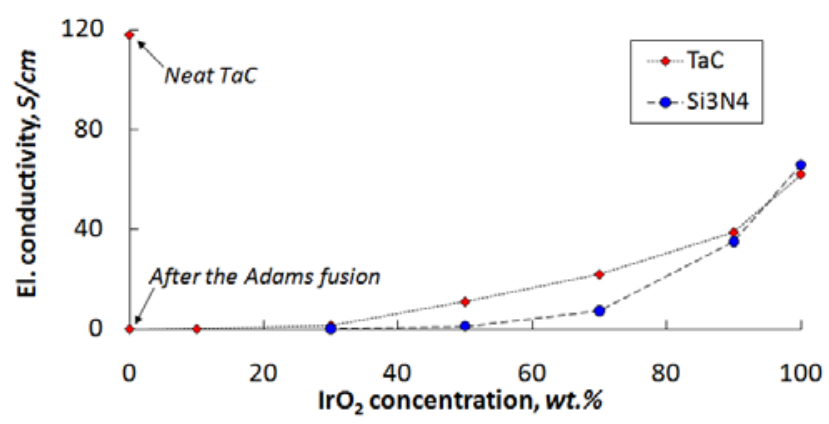

Figure 1. Electrical conductivities of the prepared $\mathrm{IrO}_{2} / \mathrm{TaC}, \mathrm{IrO}_{2} / \mathrm{Si}_{3} \mathrm{~N}_{4}$ catalysts and neat TaC support.
Figure 1 shows that conductivity for the supported catalyst decreases with increasing support content, without having plateaus or peaks and, thus suggesting no specific effect on catalyst packing with increasing content of $\mathrm{IrO}_{2}$.

At the same time results show the partial surface oxidation of $\mathrm{TaC}$ particles during the synthesis, decreasing their conductivity.

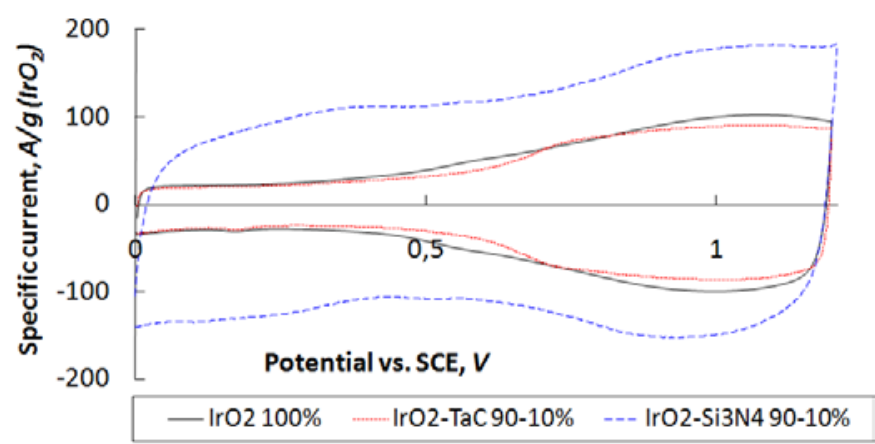

Figure 2. CV results for neat and supported $\mathrm{IrO}_{2}, 0.5 \mathrm{M}$ $\mathrm{H}_{2} \mathrm{SO}_{4}, 500 \mathrm{mV} / \mathrm{s}$

The cyclic voltammetry results shows no decrease of the catalytic activity after introducing supports. Evenmore, using $\mathrm{Si}_{3} \mathrm{~N}_{4}$, the total capacitance of the catalyst increased, suggesting an improved arrangement of the active phase on the surface.

\footnotetext{
${ }^{1}$ Ma L, Sui S, Zhai Y. Preparation and characterization of Ir/TiC catalyst for oxygen evolution. Journal of Power Sources 2008; 177(2):470e7. doi:

10.1016/j.jpowsour.2007.11.106

${ }^{2}$ Antolini E, Gonzalez E. Ceramic materials as supports for low-temperature fuel cell catalysts. Solid State Ionics 2009; 180(9e10):746e63. doi: 10.1016/j.ssi.2009.03.007. ${ }^{3}$ Schmidt T, Gasteiger H, Staeb O, Urban P, Kolb D,

Behm R. Characterization of high-surface-area electrocatalysts using a rotating disk electrode configuration. Journal of the Electrochemical Society, 145:2354-2358, 1998 doi: 10.1149/1.1838642.
} 